\title{
Biopallo-kompostit ohran lannoitteena
}

\author{
Kirsi Mäkiniemi ${ }^{1}$, Nina Perämäki ${ }^{2}$, Kaija Saastamoinen ${ }^{2}$ \\ ${ }^{1}$ Savonia-ammattikorkeakoulu, Luonnonvara-ala, Haukisaarentie 2, 74130 Iisalmi \\ ${ }^{2}$ Biopallo Systems Oy, Telkkistentie 1, 70460 KUOPIO
}

\section{Tiivistelmä}

Biopallo-kompostointireaktori muuttaa orgaanisen biojäteaineksen kompostiksi normaaliin aumakompostointiin verrattuna nopeammin. Lopputuotteena saatava maanparannusaine luokitellaan maanparannuskompostiksi. Osana Biopallo-konseptin kehittelyä oli tarpeen testata menetelmällä syntyviä maanparannuskomposteja käytännön viljelyoloissa. Kasvukaudella 2019 toteutettiin astiakoe ohralla. Kokeessa selvitettiin Biopallo-kompostien (Biopallo Juuri, Biopallo Ajo 10 sekä Biopallo Ajo 13 + Biohiili) lannoitusvaikutusta verrattuna Ecolan Agra 8-4-2 -lannoitteeseen ja lannoittamattomaan verrokkiin.

Orastumisvaiheessa lannoittamaton ja Ecolan Agra -lannoitettu ohra olivat orastuneet 9 vuorokaudessa parhaiten ja hitainta orastuminen oli Biopallo Juuri- ja Ajo 10 -komposteilla. Biopallo-komposteista orastuminen oli nopeinta Ajo 13 + Biohiili -seoksella. Orastumiserot hälvenivät seuraavan kahden viikon aikana käytännössä olemattomiksi. Tähkälletulovaiheessa Biopallo-komposteja saaneet ohrakasvustot olivat hieman pidemmällä kehityksessään kuin lannoittamaton ja Ecolan Agralla lannoitettu. Samalla mitattujen SPAD-arvojen perusteella erityisesti Biopallo Juuri -kompostia saanut ohra oli kärsinyt typen puutteesta. Myös Biopallo Ajo 13 + Biohiili -kompostin SPAD-arvo oli matala muihin paitsi lannoittamattomaan koejäseneen verrattuna. Kasvuston SPAD-arvot ennustivat lopullisen jyväsadon valkuaispitoisuutta varsin hyvin.

Satotasot olivat luomuviljelyn tavallista tasoa, satotaso oli keskimäärin $3088 \mathrm{~kg} \mathrm{ha}^{-1}$. Ecolan Agralla lannoitetulla ohralla satotaso oli korkein ja erosi erityisesti lannoittamattoman $\left(+730 \mathrm{~kg} \mathrm{ha}^{-1}\right)$ ja Biopallo Ajo 13 + Biohiili -kompostikäsittelyn $\left(+718 \mathrm{~kg} \mathrm{ha}^{-1}\right)$ saaneista koejäsenistä. Biopallo Juuri- ja Biopallo Ajo 10 -kompostikäsittelyt saaneiden koejäsenten satotasot olivat kokeessa keskimääräisiä, 3050 $3100 \mathrm{~kg} \mathrm{ha}^{-1}\left(+200-250 \mathrm{~kg} \mathrm{ha}^{-1}\right.$ lannoittamattomaan verrattuna). Jyväsadon valkuaispitoisuudet ovat matalia, keskimäärin $97 \mathrm{~g} \mathrm{~kg}^{-1} \mathrm{ka}$. Matalimmaksi valkuaispitoisuus jäi Biopallo Juuri -käsittelyllä ($14.0 \mathrm{~g} \mathrm{~kg}^{-1} \mathrm{ka}$ matalampi kuin lannoittamattomalla) ja korkein valkuaispitoisuus saatiin Biopallo Ajo 10 -kompostilla (+5.8 $\mathrm{g} \mathrm{kg}^{-1}$ ka korkeampi kuin lannoittamattomalla). Biopallo Ajo $13+$ Biohiili käsittelyn valkuaispitoisuus oli lannoittamattoman ja Ecolan Agra -lannoitetun tasoinen.

Kokeen tulosten perusteella Biopallo-komposteilla on lannoitusvaikutusta, mutta tässä kokeessa käytetyt määrät eivät riittäneet tuottamaan samaa satotasoa kuin käytännön viljelyn näkökulmasta korkeahko määrä Ecolan Agra 8-4-2 -lannoitetta. Biopallo Juuri ei sovi sellaisenaan ohran lannoitteeksi, koska se näytti edistävän ohran pakkotuleentumista ja pienensi jyväsadon valkuaispitoisuutta. Biohiilen lisääminen Biopallo-komposteihin saattaa sitoa kompostin ja maan liukoista typpeä niin, että se ei tule täysin kasvin käyttöön. Typpi saattaa kuitenkin vapautua myöhempinä vuosina. Koska tämä koe oli yksivuotinen, olisi jatkossa hyödyllistä tutkia kompostien pitkäaikaisvaikutusta.

Asiasanat: komposti, lannoittaminen, ohra 


\section{Johdanto}

Biopallo-kompostointireaktori muuttaa orgaanisen biojäteaineksen kompostiksi normaaliin aumakompostointiin verrattuna nopeammin. Materiaalina voidaan käyttää toisen ja kolmannen luokan teurastuksen sivuvirtoja. Sivutuoteasetuksen mukaisessa laitoksessa on oltava hygienisoiva käsittely, jossa on käsittelyn aikana suljetussa prosessissa saavutettava vähintään 70 asteen lämpötila vähintään tunnin ajan käsiteltävän materiaalin palakoon ollessa enintään 12 millimetriä. Materiaali murskataan ja käsitellään materiaalin lähtöpaikassa. Biopallo-reaktoriin laitetaan lisäksi haketta ja bakteeriliuos.

Koeajovaiheessa laitteisto on toiminut esikompostorina, jonka lopputuote vastaa raakakompostia tai aktiivisessa vaiheessa olevaa kompostia. Reaktorista tullut massa kypsyy loppuun aumassa 4 viikkoa. Lopputuotteena saatava maanparannusaine luokitellaan maanparannuskompostiksi. Luokittelun perustana käytetään Lannoitevalmistelain (539/2006) 6 §:n 1 momenttia, Lannoitevalmisteasetusta 24/11 ja Lannoitevalmistelakia 2006, §4. Luokittelun perustana on käytetty myös Ruokaviraston kokoamaa tyyppiluetteloa, jossa lopputuote vastaa maanparannuskompostia tyyppiluokka 3A2 orgaaniset maanparannusaineet.

Osana Biopallo-konseptin kehittelyä oli tarpeen testata menetelmällä syntyviä maanparannuskomposteja käytännön viljelyoloissa. Koska koeajoissa tehdyt Biopallo-kompostit eivät olleet kehittelyvaiheessa lakien ja asetusten mukaisesti lannoitteiksi tai maanparannusaineiksi hyväksyttyjä ja koska tuotetut kompostimäärät olivat peltomittakaavan kokeen tarpeisiin nähden liian pieniä, tehtiin lannoituskoe astiakokeena. Astiakokeessa haluttiin selvittää ohrakasvuston kehittymiseen liittyviä seikkoja sekä ohran satomäärä ja sadon laatu, kun lannoitteena käytetään Biopallo-komposteja verrattuna Ecolan Agra 8-4-2 -lannoitteen satovasteeseen.

\section{Materiaalit ja menetelmät}

Kokeeseen valittiin kolme Biopallo-koeajokompostia, joista yhden mukaan lisättiin Carbons Grow 0-4 $\mathrm{mm}$ biohiiltä (Carbons Grow 0-4 mm biohiili, Carbons Finland Oy). Kompostien raaka-aineet, pH ja ravinnepitoisuudet on esitetty Taulukossa 1.

Käyttömäärät laskettiin Savonia-ammattikorkeakoulun ympäristötekniikan laboratoriossa tehtyjen alustavien ravinneanalyysien perusteella sellaisiksi, että sekä Ecolan Agra 8-4-2:1la että kaikilla kolmella kompostilla kertyisi ympäristökorvauksen ravinteiden tasapainoisen käytön (RTK) laskentatavan mukaisesti typpeä $60 \mathrm{~kg} \mathrm{~N} \mathrm{ha}^{-1}$. Ecolan Agra 8-4-2:n kohdalla tämä tarkoitti $750 \mathrm{~kg} \mathrm{ha}^{-1}$ käyttömäärää, josta kertyy $60 \mathrm{~kg} \mathrm{ha}^{-1}$ kokonaistyppeä ja $19 \mathrm{~kg} \mathrm{ha}^{-1}$ liukoista typpeä. Komposteilla tähdättiin käyttömääriin, joissa saisi kertyä RTK:n tulkinnan mukaisesti korkeintaan $60 \mathrm{~kg} \mathrm{ha}^{-1}$ liukoista typpeä, huomioiden kuitenkin myös nitraattiasetuksen mukaisen orgaanisen kokonaistypen ylärajan $170 \mathrm{~kg} \mathrm{ha}^{-1}$. Komposteista määritettiin ravinnepitoisuudet kylvön jälkeen (Eurofins Viljavuuspalvelu, Mikkeli) komposteille säädetyillä analyysimenetelmillä ja laskettiin tulosten perusteella lopullisesti toteutuneet ravinnemäärät. Biopallo-kompostien ja verrokkilannoitteen käyttömäärät ja niistä kertyneet ravinnemäärät on esitetty taulukossa 2 .

\begin{tabular}{|l|l|c|c|c|c|c|c|}
\hline Taulukko 1. Biopallo-kompostien raaka-aineet, $\mathrm{pH}$ ja ravinnepitoisuudet \\
\hline Komposti & Raaka-aineet & $\mathrm{pH}$ & $\begin{array}{c}\text { kuiva- } \\
\text { aine } \\
\%\end{array}$ & $\begin{array}{c}\text { kokonais- } \\
\mathrm{Ng} \mathrm{kg} \\
\mathrm{ka}\end{array}$ & $\begin{array}{c}\text { liukoinen } \\
\mathrm{N} \mathrm{g} \mathrm{kg} \\
\mathrm{ka}\end{array}$ & $\begin{array}{c}\text { kokonais- } \\
\mathrm{P} \mathrm{g} \mathrm{kg}^{-1} \\
\mathrm{ka}^{-1}\end{array}$ & $\begin{array}{c}\text { kokonais- } \\
\mathrm{K} \mathrm{g} \mathrm{kg}^{-1} \\
\mathrm{ka}^{-1}\end{array}$ \\
\hline $\begin{array}{l}\text { Biopallo } \\
\text { Juuri }\end{array}$ & $\begin{array}{l}\text { Aiempi komposti, havupuuhake, } \\
\text { ruokajäte, kananlanta, } \\
\text { bakteeriliuos, sellunollakuitu, } \\
\text { kalajäte }\end{array}$ & 8.9 & 59.5 & 22.0 & 5.02 & 5.8 & 6.6 \\
\hline $\begin{array}{l}\text { Biopallo } \\
\text { Ajo 10 }\end{array}$ & $\begin{array}{l}\text { Aiempia komposteja, } \\
\text { havupuuhake, teurasjäte, veri, } \\
\text { mahalanta, kananlanta, } \\
\text { bakteeriliuos, sellunollakuitu }\end{array}$ & 8.9 & 65.4 & 20.0 & 6.11 & 3.4 & 4.5 \\
\hline $\begin{array}{l}\text { Biopallo } \\
\text { Ajo 13 }\end{array}$ & $\begin{array}{l}\text { Puutarhakalkki, luujäte, veri, } \\
\text { karjanlanta, karjanruho, } \\
\text { havupuuhake, sellunollakuitu }\end{array}$ & 7.8 & 52.8 & 16.0 & 0.77 & 7.77 & 4.3 \\
\hline
\end{tabular}




\begin{tabular}{|c|c|c|c|c|c|c|}
\hline Koejäsen/lannoituskäsittely & $\begin{array}{l}\text { Käyttömäärä } \\
\mathrm{kg} \mathrm{ha}^{-1}\end{array}$ & $\begin{array}{l}\text { YMP/RTK* } \\
\mathrm{N} \mathrm{kg} \mathrm{ha}^{*}\end{array}$ & $\begin{array}{l}\text { kokonais- } \\
\mathrm{N} \mathrm{kg} \mathrm{ha}^{-1}\end{array}$ & $\begin{array}{l}\text { liukoinen } \\
\mathrm{N} \mathrm{kg} \mathrm{ha}^{-1}\end{array}$ & $\begin{array}{l}\text { kokonais- } \\
\text { P kg ha }^{-1}\end{array}$ & $\begin{array}{l}\text { kokonais- } \\
\mathrm{K} \mathrm{kg} \mathrm{ha}^{-1}\end{array}$ \\
\hline 1 Lannoittamaton & 0 & 0 & 0 & 0 & 0 & 0 \\
\hline 2 Ecolan Agra 8-4-2 & 750 & 60 & 60 & 19 & 30 & 15 \\
\hline 3 Biopallo Juuri & 2500 & 7 & 33 & 7 & 9 & 10 \\
\hline 4 Biopallo Ajo 10 & 9950 & 40 & 129 & 40 & 23 & 29 \\
\hline $\begin{array}{l}5 \text { Biopallo Ajo } 13 \\
+ \text { Carbons Grow } 0-4 \mathrm{~mm}\end{array}$ & $\begin{array}{l}6700 \\
+2000\end{array}$ & 3 & 55 & 3 & 27 & 15 \\
\hline
\end{tabular}

*Ympäristökorvauksen ravinteiden tasapainoisen käytön laskentatavan mukaan huomioitava typpi, $\mathrm{N} \mathrm{kg} \mathrm{ha}^{-1}$

Kokeessa käytetty peltomaa oli viisi vuotta luomutuotannossa ollutta erittäin runsasmultaista hiuesavea, jonka pH oli 5.2 (välttävä), johtoluku 1.9, viljavuusfosfori $2.5 \mathrm{mg} \mathrm{l}^{-1}$ (huononlainen), kalium $95 \mathrm{mg} \mathrm{l}^{-1}$ (huononlainen) ja magnesium $120 \mathrm{mg} \mathrm{l}^{-1}$ (huononlainen). Maassa oli siis selkeä kylvölannoituksen ja pH:n nostamisen tarve. Lohkolla kasvoi maan ottovaiheessa viherlannoitukseksi viljelty valkomesikkä ja esikasvina oli ollut valkosinappi-valkomesikkäseos. Koekasviksi valittiin monitahoinen ohra, lajike oli Toria. Käytetty siemenerä oli luomusiementä, jonka itävyys oli $91 \%$. Tavoiteltu kylvötiheys oli 550 $\mathrm{kpl} \mathrm{m}{ }^{-2}$, joten $0.05 \mathrm{~m}^{2}$ :n pinta-alalle kylvömäärä oli 30 siementä. Kokeen astioina käytettiin 10 litran muovisankoja, joiden sisähalkaisija oli $25 \mathrm{~cm}$ ja pinta-ala noin $0.05 \mathrm{~m}^{2}$. Astioiden pohja rei'itettiin, jotta ylimääräisellä vedellä oli mahdollisuus päästä ulos. Astioiden tarkoituksena oli estää kasvien juuria hakeutumasta viereisten lannoituskäsittelyiden maahan.

Koe aloitettiin 27.5.2019. Peltomaa sekoitettiin ja seulottiin ja samalla maasta otettiin maanäyte. Astioiden pohjalle lisättiin ensin maata niin, että noin $20 \mathrm{~cm}$ korkeudesta jäi vapaaksi. Lannoitteeksi tulleet Ecolan Agra 8-4-2 (Ecolan Oy) ja kolme Biopallo-kompostia sekä yhden Biopallo-kompostin sekaan laitettu biohiili sekoitettiin omia astioitaan varten maamäärään, joka riitti noin $15 \mathrm{~cm}$ korkuiseksi kylvökerrokseksi. Lannoitetun maakerroksen päälle kylvettiin 30 kappaletta ohran siemeniä ja peitettiin ne vielä noin $3 \mathrm{~cm}$ lannoittamattomalla makerroksella. Kutakin lannoituskäsittelyä valmistettiin neljä astiaa. Valmiit kylvökset tiivistettiin ja kasteltiin ennen siirtoa ulos joutomaalle Lapinlahdella $\left(63^{\circ} 33^{\prime} \mathrm{N}, 27^{\circ} 31^{\prime} \mathrm{E}\right)$. Astiat aseteltiin lohkoittain (eli kerranteittain) täydellisesti satunnaistetuksi kokeeksi, jossa kukin koejäsen sijoitettiin kerran satunnaiselle paikalle jokaiseen neljään kerranteeseen (Kuva 2). Joutomaalla astioiden kasvustot altistuivat koko kasvukauden ajan alueen tavanomaisille kasvuolosuhteille. Kasvustoja ei sadetettu eikä kokeessa käytetty kasvinsuojeluaineita tai korrensäädettä.

Ohran kasvua seurattiin kasvukaudella tekemällä orastumishavainnot 9 vuorokautta kylvön jälkeen, Zadoks-kehitysastehavainnot ja SPAD-mittaus tähkälletulovaiheessa 45 vuorokautta kylvöstä lehtivihreämittarilla (HAD-YL6, Xian Yima Optoelec Co Ltd, Kiina) sekä keltatuleentumishavainnot, joiden perusteella laskettiin kasvuaika. Juuri ennen sadonkorjuuta astioista havainnoitiin lakoisuus ja kasvuston keskimääräinen pituus. Jyväsato korjattiin 30.8.201995 vuorokautta kylvöstä. Jyväsato puitiin käsin ja kuivattiin $+40{ }^{\circ} \mathrm{C}$ :ssa kiertoilmauunissa noin $13-15 \%$ kosteuteen, jäähdytettiin ja punnittiin. Jyväsadosta määritettiin satotaso $\mathrm{kg} \mathrm{ha}^{-1}(15 \%$ kosteudessa) ja tuhannen jyvän paino mekaanisesti. Jyväsadon kuiva-aine-, valkuais-, tärkkelys- ja rasvapitoisuus analysoitiin NIRSanalyysillä GrainSense ${ }^{\circledR}$-laitteella (Satolab Oy, Iisalmi).

Koejäsenten väliset erot selvitettiin varianssianalyysillä ja t-testillä/parivertailuilla (Webropol 3.0 Professional Statistics). Merkitsevyystasona pidettiin $p<0.05$ ja tilanteesta riippuen myös tendenssit $(p<0.10)$ huomioitiin.

\section{Tulokset ja tulosten tarkastelu}

Kokeen kylvön jälkeen valmistuneista kompostien ravinneanalyyseistä pystyttiin päättelemään, että ympäristötekniikan laboratorion alustavien ravinneanalyysien tulokset eivät pitäneet paikkaansa ja Biopallo-komposteista todellisuudessa kertyneet ravinnemäärät, erityisesti kokonaistyppi ja liukoinen typpi, jäivät merkittävästi pienemmiksi kuin mitä kokeen aloitusvaiheessa tavoiteltiin. Lähimmäksi verrokkilannoitteena toimineen Ecolan Agra 8-4-2:n ravinnemäärää päästiin Biopallo Ajo 10 - 
kompostilla, jolla liukoista typpeä kertyi $40 \mathrm{~kg} \mathrm{ha}^{-1}$. Biopallo Juuren ravinnemäärät olivat matalia myös fosforin ja kaliumin osalta.

Orastumisvaiheessa erot eri lannoituskäsittelyiden välillä olivat selkeät $(p<0.001)$ : lannoittamaton ja Ecolan Agra-lannoitettu ohra olivat orastuneet 9 vuorokaudessa parhaiten (Kuva 1). Orastuminen oli hitainta Biopallo Juuri- ja Ajo 10 -komposteilla. Biopallo-komposteista orastuminen oli nopeinta Ajo 13 + biohiili -seoksella. Orastumiserot hälvenivät seuraavan kahden viikon aikana käytännössä olemattomiksi (Kuva 2). Orastuminen voi viivästyä muun muassa veden tai fosforin puutoksen takia tai silloin, kun maa on kylmää. Myös juuriston voimakas alkukehitys näyttäytyy hitaampana orastumisena. Tässä kokeessa ei selvitetty eroja orastumisnopeuksissa, mutta maan lämpötilamittausten perusteella voitiin todeta, etteivät erot orastumisessa johtuneet ainakaan lämpötilaeroista.

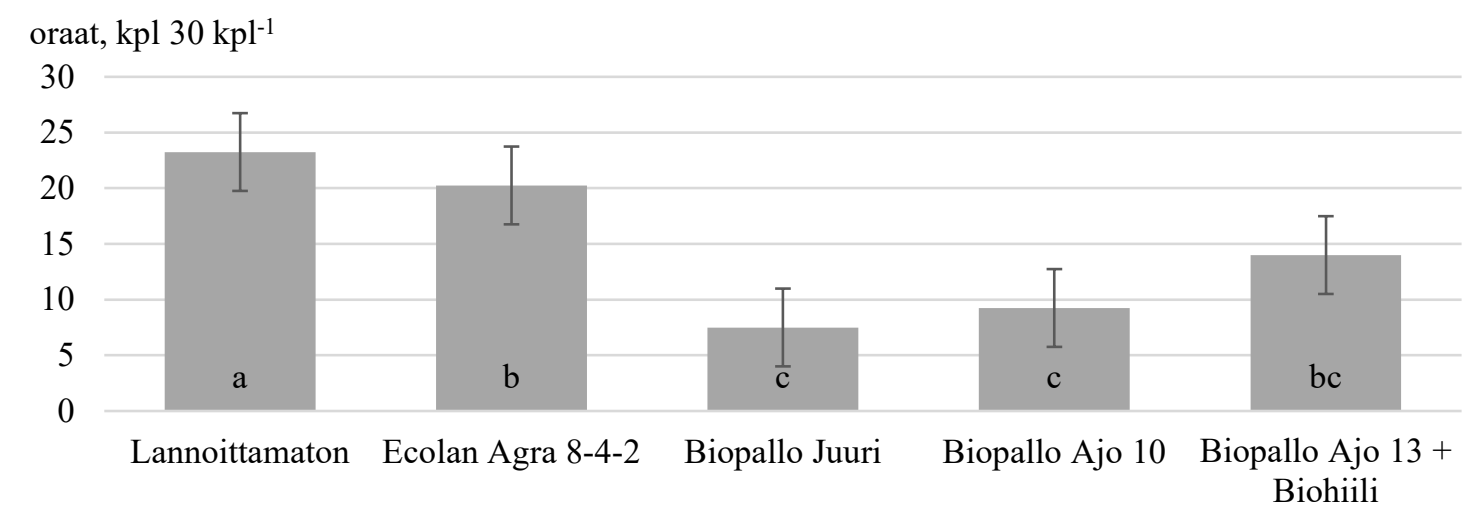

Kuva 1. Ohran orastuminen 9 vrk kylvöstä Biopallo-komposteilla tehdyssä astiakokeessa. Kuhunkin astiaan oli kylvetty 30 siementä. Virhepalkit kuvaavat keskivirheen keskihajontaa ja aakkoset parivertailun eroja.

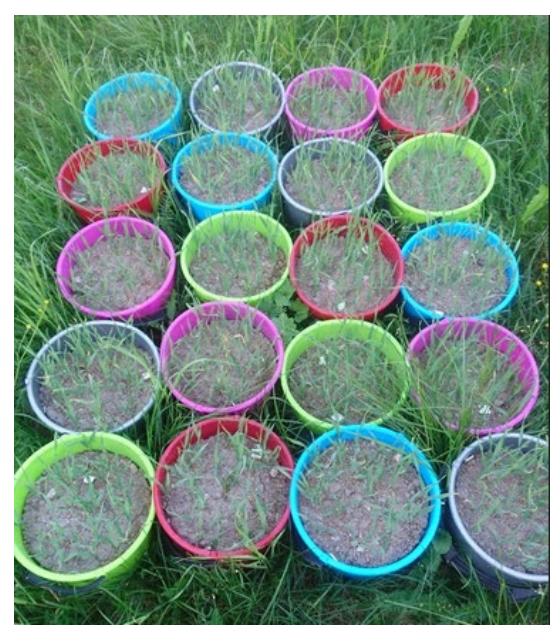

Kuva 2. Koeastioiden asettelu (kerranteet vasemmalta oikealle) ja ohran orastuminen 3 viikkoa kylvöstä.

Tähkälletulovaiheessa, 45 vuorokautta kylvöstä, havaittiin myös selviä eroja eri lannoituskäsittelyiden välillä kasvuston kehitysasteessa ja lehtivihreäpitoisuutta kuvaavissa SPAD-arvoissa. Biopallokomposteja saaneet ohrakasvustot olivat hieman pidemmällä kehityksessään kuin lannoittamaton ja Ecolan Agralla lannoitetut (Kuva 3, $p=0.04$ ). Näistä Biopallo Juuri -kompostia saaneet ohrat olivat muista poiketen ehtineet kehitysasteelle 55. Aikaistunut kehitys voi liittyä esimerkiksi veden tai typen puutteesta johtuvaan pakkotuleentumiseen. Tilastollisesti merkitsevistä eroista huolimatta erot eivät olleet käytännön tasolla suuria.

SPAD-arvojen perusteella erityisesti Biopallo Juuri -kompostia saanut ohra oli kärsinyt typen puutteesta (Kuva 4, $p=0.001$ ). Myös Biopallo Ajo $13+$ biohiili -kompostin SPAD-arvo oli matala 
muihin paitsi lannoittamattomaan koejäseneen verrattuna. Syynä tähän on ollut ainakin molempien koejäsenten saamat erittäin matalat liukoisen typen määrät sekä mahdollisesti Biopallo Ajo 13 + biohiili -seoksen kyky sitoa ravinteita maahan, jolloin ne eivät vapaudu nopeasti viljelykasvin otettavaksi. Typen riittävyys oli paras Ecolan Agralla $\left(60 \mathrm{~kg} \mathrm{~N} \mathrm{ha}^{-1}\right.$, josta liukoista $\left.19 \mathrm{~kg} \mathrm{ha}^{-1}\right)$ ja Biopallo Ajo 10 kompostilla (40 kg liukoista $\left.\mathrm{N} \mathrm{ha}^{-1}\right)$ lannoitetulla sekä lannoittamattomalla $\left(0 \mathrm{~kg} \mathrm{~N}^{-1}\right)$ ohralla. Tulos kuvastaa sitä, että maaperässä on ollut kasveille kelpoista liukoista typpeä luontaisesti tarjolla, mahdollisesti esikasvin jättämänä tai orgaanisesta aineksesta mineralisoituneena.

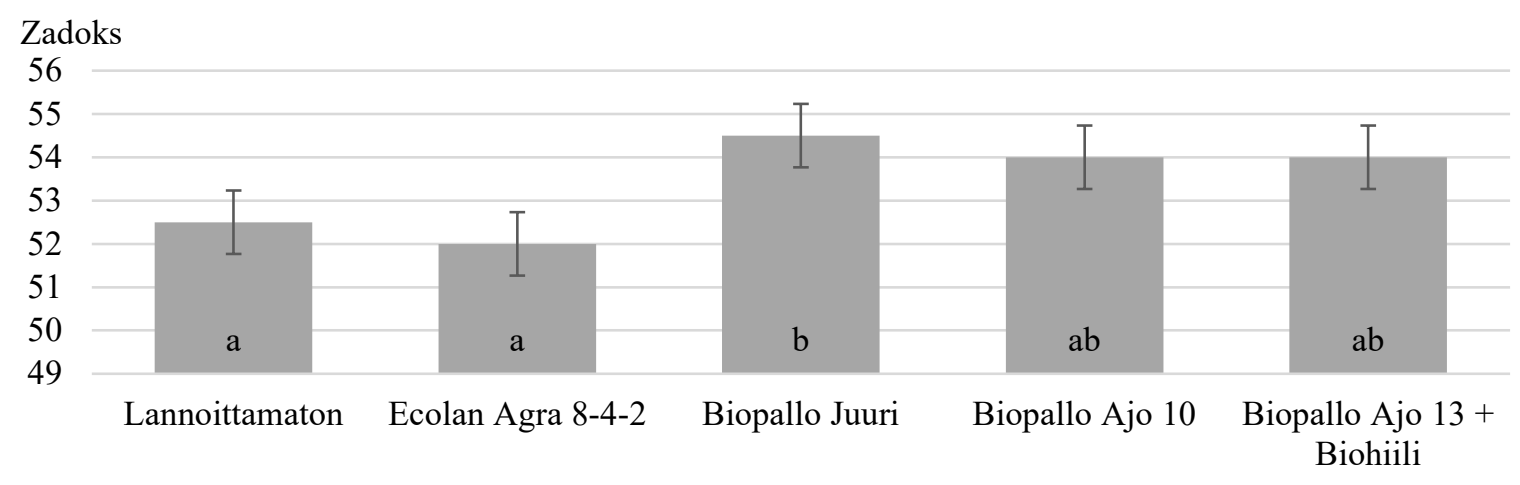

Kuva 3. Ohran kehitysasteet 45 vuorokautta kylvöstä Biopallo-komposteilla tehdyssä astiakokeessa. Virhepalkit kuvaavat keskivirheen keskihajontaa ja aakkoset parivertailun eroja.

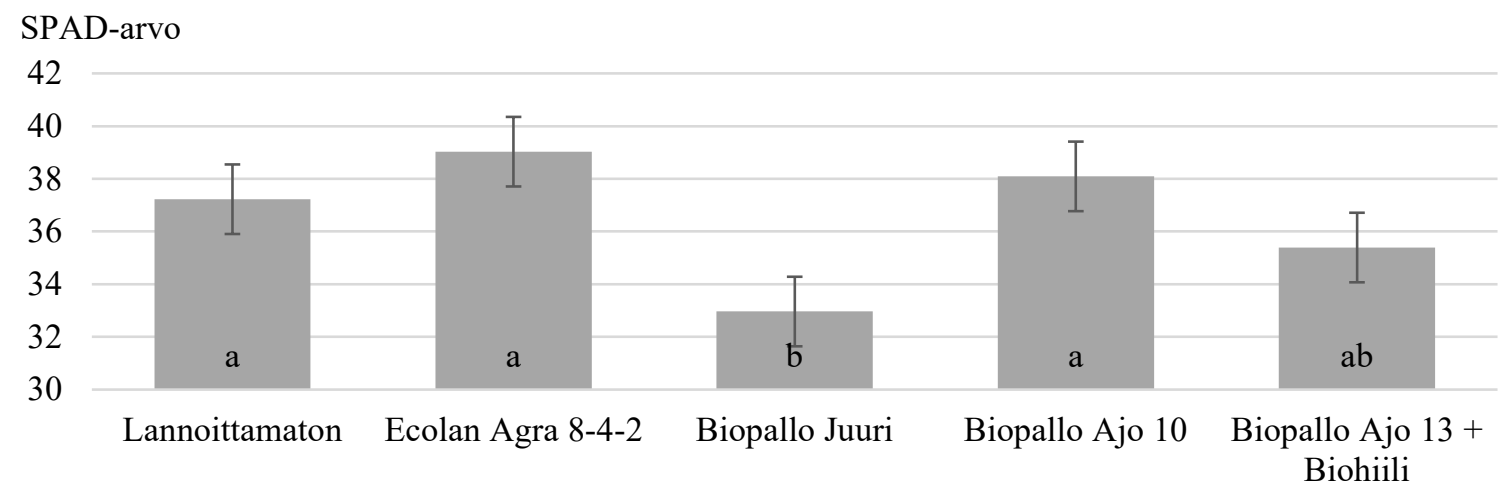

Kuva 4. Ohran SPAD-arvot 45 vuorokautta kylvöstä Biopallo-komposteilla tehdyssä astiakokeessa. Virhepalkit kuvaavat keskivirheen keskihajontaa ja aakkoset parivertailun eroja.

Satotasot olivat luomuviljelyn tavallista tasoa, satotaso oli keskimäärin $3088 \mathrm{~kg} \mathrm{ha}^{-1}$ (Kuva 5). Tilastollisesti merkitseviä eroja käsittelyiden välillä ei havaittu $(p=0.20)$, mutta parivertailuissa Ecolan Agralla lannoitetulla ohralla satotaso erosi lannoittamattoman $\left(+730 \mathrm{~kg} \mathrm{ha}^{-1}\right)$ ja Biopallo Ajo $13+$ Biohiili -kompostikäsittelyn (+718 $\left.\mathrm{kg} \mathrm{ha}^{-1}\right)$ saaneista koejäsenistä. Biopallo Juuri- ja Biopallo Ajo 10 -kompostikäsittelyt saaneiden koejäsenten satotasot olivat kokeessa keskimääräisiä, $3050-3100 \mathrm{~kg}$ $\mathrm{ha}^{-1}\left(+200-250 \mathrm{~kg} \mathrm{ha}^{-1}\right.$ lannoittamattomaan verrattuna).

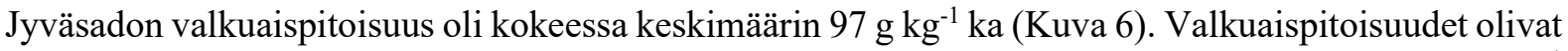
siten huomattavan matalia verrattuna Toria-lajikkeen keskimääräiseen valkuaispitoisuuteen $113 \mathrm{~g} \mathrm{~kg}^{-1}$ ka (Luonnonvarakeskus 2019). Matalimmaksi valkuaispitoisuus jäi Biopallo Juuri -käsittelyllä (-14.0 $\mathrm{g} \mathrm{kg}^{-1} \mathrm{ka}$ matalampi kuin lannoittamattomalla, $\left.p=0.010\right)$ ja korkein valkuaispitoisuus saatiin Biopallo

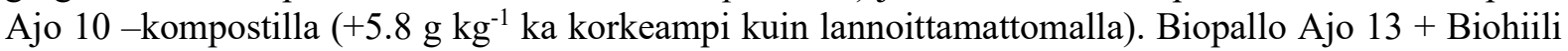
-käsittelyn valkuaispitoisuus oli lannoittamattoman ja Ecolan Agra -lannoitetun tasoinen. Kasvuston SPAD-arvot ennustivat lopullisen jyväsadon valkuaispitoisuutta koejäsenten keskiarvojen tasolla tarkasteltuna varsin hyvin $\left(\mathrm{R}^{2}=0.78\right)$. 


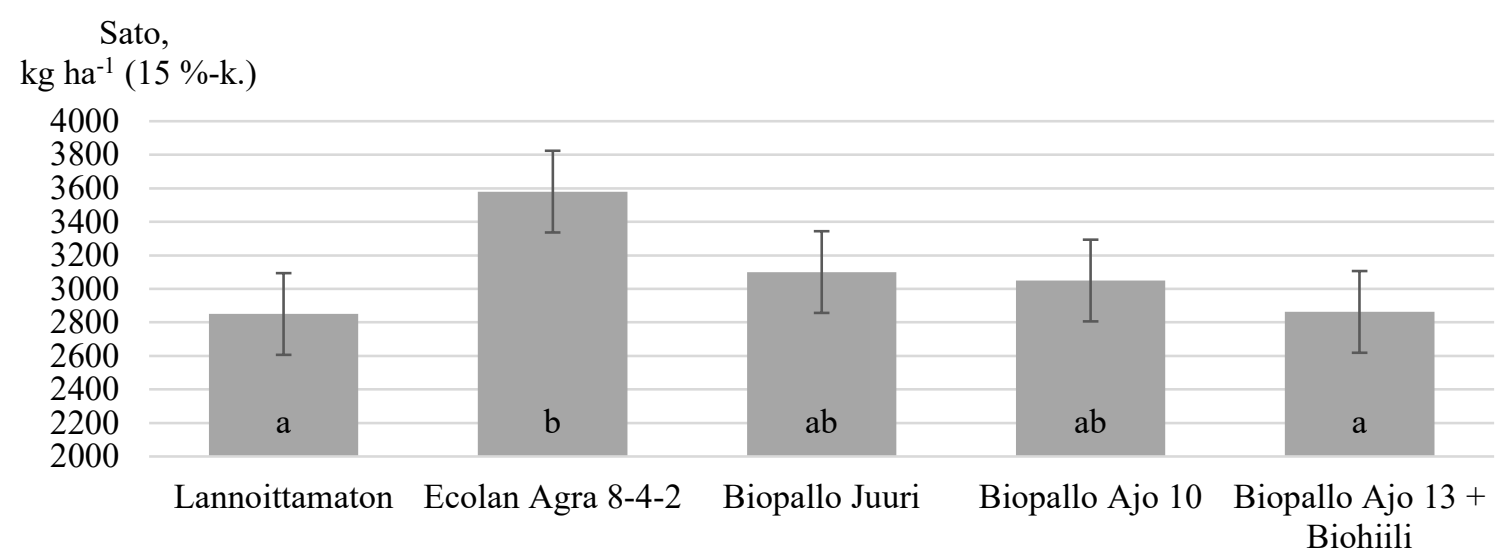

Kuva 5. Ohran satotaso $\mathrm{kg} \mathrm{ha}^{-1}$ (15\% kosteudessa) Biopallo-komposteilla tehdyssä astiakokeessa. Virhepalkit kuvaavat keskivirheen keskihajontaa.

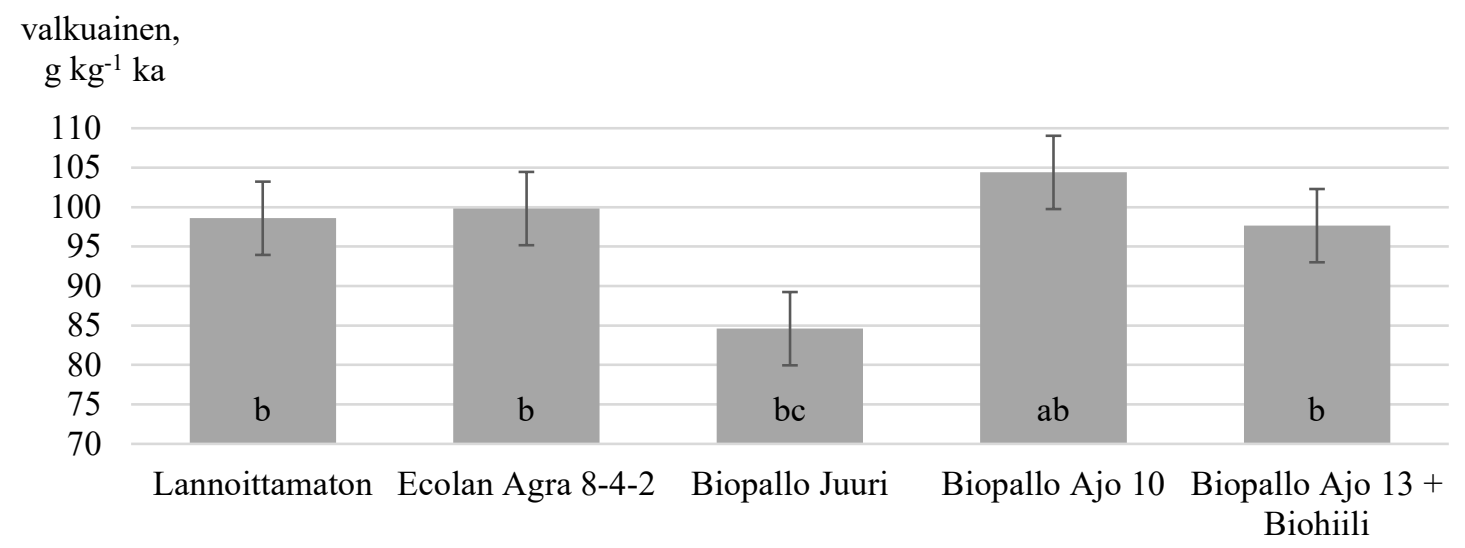

Kuva 6. Ohran valkuaispitoisuudet $\left(\mathrm{g} \mathrm{kg}^{-1} \mathrm{ka}\right)$ Biopallo-komposteilla tehdyssä astiakokeessa. Virhepalkit kuvaavat keskivirheen keskihajontaa ja aakkoset parivertailun eroja.

\section{Johtopäätökset}

Kokeen tulosten perusteella Biopallo-komposteilla on lannoitusvaikutusta, mutta tässä kokeessa Biopallo-kompostien käyttömäärät olivat kompostien todellisia ravinnepitoisuuksia heikosti kuvanneiden ennakkoanalyysien takia liian pienet kunnollisen lannoitusvaikutuksen saamiseksi. Kokeessa käytetyt kompostimäärät eivät riittäneet tuottamaan samaa satotasoa kuin käytännön viljelyn näkökulmasta korkeahko määrä Ecolan Agra 8-4-2 -lannoitetta. Biopallo Juuri ei sovi sellaisenaan ohran lannoitteeksi, koska sen ravinnepitoisuus on matala; se näytti edistävän ohran pakkotuleentumista ja pienensi jyväsadon valkuaispitoisuutta. Biohiilen lisääminen Biopallo-komposteihin saattaa sitoa kompostin ja maan liukoista typpeä niin, että se ei tule täysin kasvin käyttöön. Typpi saattaa kuitenkin vapautua myöhempinä vuosina. Koska tämä koe oli yksivuotinen, olisi jatkossa hyödyllistä tutkia kompostien pitkäaikaisvaikutusta.

Kokeen ohrasadon laatutuloksia sekä Biopallo-kompostien vaikutuksia peltomaan viljavuuteen, Fusarium-sienten määrään ja maan mikrobiaktiivisuuteen on selvitetty tätä raporttia tarkemmin. Nämä tulokset julkaistaan erillisessä raportissa.

\section{Kirjallisuus}

Luonnonvarakeskus 2019. Ohra, 2011-2018, Viralliset lajikekokeet. Tutkimustulostietokanta, Luke/Lajikekokeet. Lainattu 29.1.2020.

http://px.luke.fi/PXWeb/pxweb/fi/maatalous/maatalous_lajikekokeet_julkaisuvuosi_2018_sato_ohra/14010 0sato_ohra.px/?rxid=410d8271-72f5-455f-8b46-f5ec2fi191f6d 